Ann. Biol. anim. Bioch. Biophys., 1979, 19 (4 A), 999-1005.

\title{
The influence of magnesium deficiency on inflammatory reaction in rats
}

\author{
par Régine DELAIGUE, P. DUCHENE-MARULLAZ \\ with the technical assistance of $M$. BARDIN and M. C. RANCE \\ Laboratory of Hydrology, Foculty of Medicine \\ 63001 Clermont-Ferrand Cedex, France.
}

\begin{abstract}
Summary. The inflammatory reactions obtained in magnesium-deficient rats, by injecting carrageenin into the paw or around cotton pellets introduced under the skin, were not different from those of normal animals. In contrast, the volume of pleural exudate provoked by intrapleural injection of $\mathrm{AgNO}_{3}$ was greater in deficient rats. Phenylbutazone reduced the exudate volume similarly in control and deficient rats. Mepyramine, specifically blocking $H_{1}$ receptors, only slightly reduced the intensity of the inflammatory reaction in deficient rats. On the other hand, promethazine removed any difference between the two groups of animals. That substance not only blocked the histamine receptors, but also the effects of serotonin, and reduced the usual increase in vascular permeability. The physiopathology of inflammatory reactions observed in magnesiumdeficient rats could not be explained only by histamine liberation ; other parameters such as serotonin release, protein change or vascular permeability modifications might be involved.
\end{abstract}

\section{Introduction.}

Magnesium deficiency in rats causes considerable peripheral vasodilatation with hyperemia and edema (Mc Collum and Orent, 1931 ; Kruse ef al., 1932) associated with scratching lesions, thus producing a typical allergic reaction (Bois et al., 1960). It has been suggested that these phenomena are related to mast cell histamine liberation (Belanger ef al., 1957). However, the gastric mucosa in rats appears to be largely responsible for the increase in circulating histamine observed during magnesium deficiency (Bois et al., 1963 ; Cantin and Veilleux, 1972). It was found that experimental magnesium deficiency enhanced development of the inflammatory processes after formaldehyde was injected into the paws of rats (Jasmin, 1961). We have studied this problem again in the present paper, using different experimental inflammatory models.

\section{Material and methods.}

Animals and diets. - Male Wistar rats having a mean weight of $190 \pm 5 \mathrm{~g}$ were used. A magnesium deficiency was rapidly produced by feeding the rats an appro- 
priate diet (table 1) for 21 days containing $30 \mathrm{mg}$ magnesium $/ \mathrm{kg}$ (Rayssiguier et al., 1973).

\section{TABLE 1}

Composition $(\mathrm{g} / \mathrm{kg})$ of basal magnesium-deficient diet

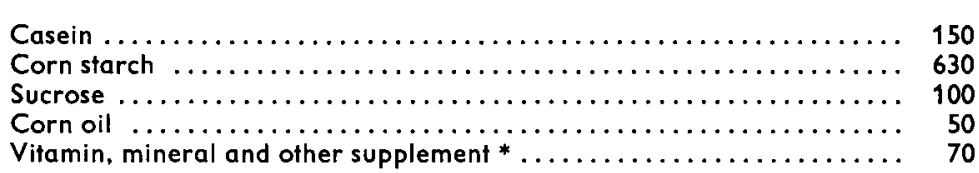

* Supplied per $\mathrm{kg}$ diet : L cystine $3 \mathrm{~g} ; \mathrm{L}$ tryptophan $0.5 \mathrm{~g}$; choline chloride $1 \mathrm{~g} ;$ myo-inositol $300 \mathrm{mg}$; ascorbic acid $100 \mathrm{mg}$; p-aminobenzoic acid $100 \mathrm{mg}$; nicotinamide $50 \mathrm{mg}$; calcium pantothenate $50 \mathrm{mg}$; alpha-tocopherol $30 \mathrm{mg}$; riboflavin $10 \mathrm{mg}$; thiamin $10 \mathrm{mg}$; phylloquinone $5 \mathrm{mg}$; pyridoxin $5 \mathrm{mg}$; pteroylmonoglutamic acid $1 \mathrm{mg}$; biotin $0.2 \mathrm{mg}$; cyanocobalamin $0.05 \mathrm{mg}$; retinol $1.72 \mathrm{mg}$; cholecalciferol $2.5 \mu \mathrm{g} ; \mathrm{CaCO}_{3} 18 \mathrm{~g} ; \mathrm{KH}_{2} \mathrm{PO}_{4} 13.6 \mathrm{~g} ; \mathrm{NaCl} 10 \mathrm{~g}$; iron ammonium citrate $1.6 \mathrm{~g} ; \mathrm{MnSO}_{4} \mathrm{H}_{2} \mathrm{O} 150 \mathrm{mg} ; \mathrm{ZnSO}_{4} 7 \mathrm{H}_{2} \mathrm{O}: 150 \mathrm{mg} ; \mathrm{CuSO}_{4} .5 \mathrm{H}_{2} \mathrm{O} 40 \mathrm{mg} ; \mathrm{KIH}: 3 \mathrm{mg} ; \mathrm{Na}_{2} \mathrm{SO}_{3}$ $0.2 \mathrm{mg}$.

Control rats received the same food containing $1 \mathrm{~g}$ magnesium $/ \mathrm{kg}$. The animals were kept in metabolism cages and were weighed on experimental days 10 and 21 . The quantifies of food ingested were paired in the two groups.

\section{Experimental inflammation models.}

Carrageenin edema test (Winter et al., 1962). $0.1 \mathrm{ml}$ of a $1 \mathrm{p} .100$ carregeenin suspension was injected under the plantar aponevrosis of the right hind paw. Paw volume was measured by plethysmography every hour for $7 \mathrm{hrs}$. Edemic changes in deficient animals were compared with those observed in control rats.

$\mathrm{AgNO}_{3}$-induced pleurisy (Spector, 1956 ; Wilhelmi, 1965). Under slight ether narcosis $1.5 \mathrm{ml}$ of air was injected into the pleural cavity. $0.3 \mathrm{ml}$ of a 0.4 p. 100 aqueous solution of $\mathrm{AgNO}_{3}$ (Merck) was introduced into the pouch thus obtained. The animals were killed by ether inhalation 7 hrs later. The volume of exudate collected in control animals was compared to that obtained from treated animals.

Cotton pad granuloma test (Meier ef al., 1950). Inflammatory granuloma was provoked on day 10 of deficiency. Under slight ether anesthesia sterile cotton pellets of $80 \pm 2 \mathrm{mg}$, imbibed with a 1 p. 100 solution of carregeenin, were placed under the skin of each axillary fold. The animals were killed on day 21 . The granulomas were dissected and then dried in an oven at $60^{\circ} \mathrm{C}$ for 48 hrs. Granuloma weights of the treated rats were compared with those of the control animals.

Carrageenin edema was induced in 14 control animals and 28 deficient rats.

$\mathrm{AgNO}_{3}$ pleurisy was induced in 30 control animals and 36 deficient rats divided into 5 groups. In the case of experimental pleurisy only, the series of normals and deficients were treated $30 \mathrm{~min}$. before $\mathrm{AgNO}_{3}$ injection with various pharmacodynamic agents : $150 \mathrm{mg} / \mathrm{kg}$ phenylbutazone (esophagian intubation), $1.25 \mathrm{mg} / \mathrm{kg}$ (MI) mepy- 
ramine, $1.25,2.5$ and $5 \mathrm{mg} / \mathrm{kg}(\mathrm{MI})$ promethazine. The results of the treated rats and the controls in one trial were compared.

Cotfon pad granuloma was induced in 17 normal and 20 deficient rats in three series.

The blood concentrations of magnesium and calcium were measured on days 10 and 21. The blood, sampled by cardiac punction, was centrifuged for 2 min. ; measurements were made by atomic absorption (Perkin Elmer 290B).

Using Student's-test, the results were statistically computed, with the means and standard errors, as a complete series for each test.

\section{Results.}

1. - At about day 7 of magnesium deficiency, the rats showed the classic hyperemia of the ears reported by all authors since Mc Collum and Orent (1931) and the usual weight loss. Variations in animal weight and in the plasma magnesium and calcium levels are shown in table 2 . Blood magnesium concentration remained constant in the control rats. In general, this level dropped significantly $(P<0.01)$ in the deficient animals at days 10 and 21 . Blood calcium concentration did not change significantly.

\section{TABLE 2}

Changes in weight and plasma $\mathrm{Mg}$ and $\mathrm{Ca}$ concentrations of normal rats and those subjected to a mognesium-deficient dief

\begin{tabular}{|c|c|c|c|c|c|c|}
\hline & \multicolumn{3}{|c|}{ Control animals } & \multicolumn{3}{|c|}{ Deficient animals } \\
\hline & Control & 10 days & 21 days & Control & 10 days & 21 days \\
\hline $\begin{array}{l}\text { Weight } \\
\text { (in g) }\end{array}$ & $\begin{array}{c}190 \pm 0,5 \\
n=91\end{array}$ & $\begin{array}{c}224 \pm 7 \\
n=91\end{array}$ & $\begin{array}{c}255 \pm 8 \\
n=91\end{array}$ & $\begin{array}{l}190 \pm 5 \\
n=120\end{array}$ & $\begin{array}{l}212 \pm 5 \\
n=120\end{array}$ & $\begin{array}{l}220 \pm 4 \\
n=120\end{array}$ \\
\hline $\begin{array}{c}\mathrm{Mg} \\
(\mathrm{mg} / 100 \mathrm{ml})\end{array}$ & \multicolumn{3}{|c|}{$\begin{array}{c}1.59 \pm 0.05 \\
n=60\end{array}$} & $\begin{array}{c}1.59 \pm 0,05 \\
n=90\end{array}$ & $\begin{array}{c}0.64 \pm 0.02 * * \\
n=90\end{array}$ & $\begin{array}{c}0.55 \pm 0.03 * * \\
n=90\end{array}$ \\
\hline $\begin{array}{c}\mathrm{Ca} \\
(\mathrm{mg} / 100)\end{array}$ & \multicolumn{3}{|c|}{$\begin{array}{c}10.9 \pm 0.15 \\
n=60\end{array}$} & $\begin{array}{c}10.9 \pm 0.12 \\
\mathrm{n}=90\end{array}$ & $\begin{array}{r}11.1 \pm 0.12 \\
\mathrm{n}=90\end{array}$ & $\begin{array}{c}11.4 \pm 0.11 \mathrm{~ns} \\
n=90\end{array}$ \\
\hline
\end{tabular}

Statistical significance : ${ }^{* *} \mathrm{P}<0.01, \mathrm{n}=$ number of animals.

2. - Injection of carrageenin caused edema of the paw which increased regularly during the $7 \mathrm{hrs}$ of observation. However, there was no difference in volume increase in deficient and control rats.

3. - The weight of the tissue characterizing the cotton pad granuloma and developing around the foreign body was not different in the two experimental series : $704 \pm 44 \mathrm{mg}(\mathrm{n}=17)$ in controls, and $694 \pm 46(n=20)$ in deficient rats. 
4. - The volume of pleural exudate was much higher in the deficient animals than in the controls (table 3). Phenylbutazone significantly reduced the liquid volumes extracted from the pleural cavity, but did not change the difference observed between the deficient animals and controls. Mepyramine did not modify the pleural reaction in any case. No dose of promethazine had no significant effect on the pleural exudate, but it removed all differences between deficient and control animals.

TABLE 3

Influence of magnesium deficiency on pleural exudate volume Exudate collected $6 \mathrm{hrs}$ after intra-pleural insertion of $\mathrm{AgNO}_{3}$

\begin{tabular}{|c|c|c|c|c|}
\hline Total animals & \multicolumn{2}{|c|}{$\begin{array}{l}\text { Non-deficient animals } \\
4.71 \pm 0.11 \quad n=30(1)\end{array}$} & \multicolumn{2}{|c|}{$\begin{array}{c}\text { Mg-deficient animals } \\
5.79 \pm 0.11^{* * *} \quad \mathrm{n}=36(\mathrm{a})\end{array}$} \\
\hline $\begin{array}{l}\text { Phenylbutazone }(150 \mathrm{mg} / \mathrm{kg} \mathrm{p.} \mathrm{o}) \\
\text { Control } \ldots \ldots \ldots \ldots \ldots \ldots \ldots \ldots \ldots \ldots \ldots \ldots \ldots \ldots\end{array}$ & $\begin{array}{l}4.87 \pm 0.24 \\
2.51 \pm 0.10\end{array}$ & $\begin{array}{l}n=8(2) \\
n=29(3)\end{array}$ & $\begin{array}{l}6.07 \pm 0.10 * * \\
3.26 \pm 0.10^{* *}\end{array}$ & $\begin{array}{l}n=12(b) \\
n=34(c)\end{array}$ \\
\hline $\begin{array}{l}\text { Mepyramine }(1,25 \mathrm{mg} / \mathrm{kg} \text { I. M.) } \\
\text { Control } \ldots \ldots \ldots \ldots \ldots \ldots \ldots \ldots \ldots \ldots \ldots \ldots \ldots\end{array}$ & $\begin{array}{l}4.65 \pm 0.16 \\
4.34 \pm 0.20\end{array}$ & $\begin{array}{l}n=14(4) \\
n=16(5)\end{array}$ & $\begin{array}{l}5.46 \pm 0.18 * * \\
5.31 \pm 0.15 * *\end{array}$ & $\begin{array}{l}n=14(d) \\
n=16(e)\end{array}$ \\
\hline 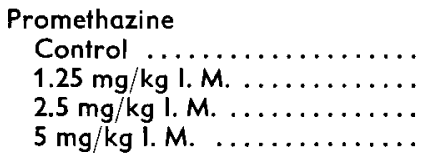 & $\begin{array}{l}4.68 \pm 0.24 \\
4.62 \pm 0.22 \\
4.39 \pm 0.16 \\
3.57 \pm 0.12\end{array}$ & $\begin{array}{l}n=8(6) \\
n=11(7) \\
n=14(8) \\
n=14(9)\end{array}$ & $\begin{array}{l}5.90 \pm 0.20 * * \\
4.76 \pm 0.18 \text { N.S. } \\
4.15 \pm 0.17 \text { N.S. } \\
3.66 \pm 0.12 \text { N.S. }\end{array}$ & $\begin{array}{l}n=10(\mathrm{f}) \\
\mathbf{n}=15(\mathrm{~g}) \\
\mathbf{n}=13(\mathrm{~h}) \\
\mathbf{n}=25(\mathrm{i})\end{array}$ \\
\hline
\end{tabular}

The statistical significance of : $*: P<0,05, * *: P<0,01, * * *: P<0,001$, appearing on the table represents a comparison of the results on control and deficient animals.

Additional comparisons are : Different at 1 p. 1000 llevel : values 2 and $3, \mathrm{~b}$ and $c$, 6 and 9,7 and g, 7 and $h, f$ and i. Different at 1 p. 100 level : values 1 and 3,1 and 5, a and $d, a$ and e. Different at 5 p. 100 level : values 6 and $9, f$ and $i$.

\section{Discussion.}

Magnesium deficiency was certainly effective, as our measurements of blood magnesium concentrations and clinical observations agree with earlier reports (Mc Collum and Orent, 1931 ; Bois et al., 1960).

The primary type inflammatory reaction caused by carrageenin involves numerous mediators, principally histamine. This substance may be responsible for capillary exudation because antihistamines very significantly reduce the volume of edema thus created (Niemegeers et al., 1964). This edema may involve two separate mechanisms since pharmaocdynamic agents inhibit certain types of edema but do not affect others (Silvestrini, 1964).

The introduction of a cotton pellet under the skin of the rat is an experimental model which provides more information than the preceding one about the secondary inflammatory reactions observed in human pathology, especially those which develop 
around a foreign body. However, the conjunctive reaction created in deficient rats is not different, at least quantitatively, from that in normal animals.

In contrast, magnesium deficiency considerably increases the volume of pleural exudate which can be collected in rats $7 \mathrm{hrs}$ after injection of $\mathrm{AgNO}_{3}$ into the pleura. Several reasons for this may be postulated since numerous mediators are liberated in the inflammatory model. Phenylbutazone, which has a known inhibitory action on prostaglandin synthesis, certainly reduced the intensity of the pleural reaction in the two series. However, there remained a significant difference $(P<0.01)$ between the exudate volume of deficient animals $(3.26 \pm 0.10 \mathrm{ml})$ and that of normal ones $(3.51 \pm 0.10 \mathrm{ml})$. Using the same inflammatory model, Fontagne et al. (1974) have already shown that phenylbutazone $(200 \mathrm{mg} / \mathrm{kg}$ per os) considerably reduced the exudate volume collected $6 \mathrm{hrs}$ after $\mathrm{AgNO}_{3}$ injection. Thus, magnesium deficiency does to appear to influence phenylbutazone effect. However, some anti-inflammatories cause anomalies in magnesium metabolism. The salicylates increase magnesium turnover, causing its tissular loss (Aikawa and Reardon, 1966), increase plasma magnesium concentration (Charnock et al., 1962) and modify its tubular reabsorption Ramsay and Eliott, 1967), inducing hypermagnesuria. Corticoid secretion is also reduced during magnesium deficiency (Elin et al., 1970).

Whatever the case, the increased pleural reaction in magnesium-deficient rats cannot be explained by enhanced liberation of prostaglandins.

The hypothesis of increased histamine release can also be discounted since there is no difference in reactivity between the two series of animals as regards carrageenininduced paw inflammation. Histamine liberation plays an important role in the evolution of this edema.

We nevertheless verified this fact in $\mathrm{AgNO}_{3}$ pleurisy using two antihistamines, mepyramine and promethazine. Mepyramine has no property other than that of blocking the histamine receptors. Its use did not significantly reduce the volume of pleural exudate in deficient and non-deficient animals (series 4 and 5 and $d$ and $e$ of table 2). However, the difference is significant $(P<0.01)$, if all the animals (series 1 and a) of table 2 are compared with all those treated with mepyramine (series 5 and e). Fontagne ef al. (1974) did not observe any reduction in exudate volume collected 3 hrs after $\mathrm{AgNO}_{3}$ injection.

In addition to its effects on histamine receptors, promethazine reduces the effects of serotonin and slightly attenuates the increase in vascular permeability caused by various inflammation mediators (Spector and Willoughby, 1959 ; Halpern et al., 1963). At all doses, promethazine removed differences of reactivity between deficient and control animals. The highest dose $(5 \mathrm{mg} / \mathrm{kg} \mathrm{Ml})$ even again reduced $(P<0.05)$ the exudate volume equally in the two experimental series. It is therefore probable that serotonin is implicated in the greater pleural reactivity during magnesium deficiency. Further, Itokawa et al. (1972) have shown that experimental magnesium deficiency is accompanied by increased serotonin liberation.

In conclusion, a magnesium deficit increased the intensity of the inflammatory reaction in only one experimental model. That increase could be only partially explained by increased histamine liberation ; under the effect of the deficiency, mepyramine, a specific $\mathrm{H}_{1}$ receptor blocker, reduced the process but did not cause it to disappear. In contrast, promethazine completely corrected the pleural hypersecretion caused by 
magnesium deficiency by opposing the effects of serotonin and reducing vascular permeability in addition to blocking histamine receptors.

The physiopathology of inflammatory reactions observed in magnesium-deficient rats cannot be explained only by histamine liberation; other parameters must be taken into account such as serotonin release related to mast cell degranulation (ltokawa et al., 1972), protein change (Rayssiguier et al., 1977) or vascular permeability modification. Further experiments are under way in order to determine the respective roles of these different factors in inflammatory reactions in magnesium-deficient rats.

Reçu en novembre 1978
Accepté en janvier 1979.

Acknowledgements. - We wish to thank P. Larvor and Y. Rayssiguier (INRA, Laboratoire des Maladies métaboliques) for their excellent advice. This work was supported by the ASDRT.

Résumé. Chez des rats carencés en magnésium, les réactions inflammatoires réalisées par injections de carragénine dans la patte ou autour de pellets de coton introduits sous la peau, ne sont pas différentes de celles observées chez des rats normaux. Par contre, le volume de l'exsudat pleural provoqué par l'injection intra-pleurale de nitrate d'argent est plus important chez les rats carencés. La phénylbutazone réduił le volume de l'exsudat chez des rats carencés comme chez les témoins. La mépyramine bloquant spécifique des récepteurs $\mathrm{H}_{1}$ ne diminue que légèrement l'intensité de la réaction inflammatoire chez les carencés. Par contre, la prométhazine supprime toute différence entre les deux groupes d'animaux. Or, elle intervient non seulement sur les récepteurs à l'histamine mais bloque aussi les effets de la sérotonine. Elle atténuerait également l'augmentation de la perméabilité vasculaire.

La physiopathologie de la réaction inflammatoire observée au cours du déficit magnésique du rat ne peut donc pas se résumer aux conséquences d'une simple décharge d'histamine. D'autres paramètres interviennent : décharge de sérotonine, altération protéique ou troubles de la perméabilité vasculaire.

\section{References}

AIKAWA J. K., REARDON J. Z., 1966. Effect of sodium salicylate on $\mathrm{Mg}$ metabolism in the rabbit. Proc. Soc. exp. Biol. Med., 122, 884-887.

BELANGER L. F., VAN ERKEL G. A., JAKEROW A., 1957. Behavior of the dermal mast cells in Mg deficient rats. Science, 126, 3262, 29-30.

BOIS P., BYRNE E. H., BELANGER L. F., 1960. Effect of Mg deficiency on the regeneration of mast cells after treatment with 48-80 in rats. Can. J. Biochem., 38, 585-589.

BOIS P., GASCON A., BEAUNES A., 1963. Histamine-liberating effect of magnesium deficiency in the rat. Nature, 197, 501-502.

CANTIN M., VEILLEUX R., 1972. Globules, leucocytes and mast cells of the urinary tract in Mg deficient rats. Chemical and election microscopic study. Lab. Invest., 27, 495-507.

CHARNOCK J. S., LOCKETT R., HETZEL B. S., 1962. Effect of salicylate on plasma Mg levels. Nature, 195, 295-296.

ELIN R. J., ARMSTRONG W. D., SINGER L., 1970. Adrenal gland factors in magnesium deficient rats. Proc. Soc. exp. Biol. Med., 134, 542-547.

FONTAGNE J., STOCHLA C., LECHAT P., 1974. Pleurésie expérimentale provoquée chez le rat par le nitrate d'argent. J. Pharmacol. (Paris), 5, 13-26.

HALPERN B. N., NEVEU T., SPECTOR S., 1963. The nature of the chemical mediators involved in anaphylactic reactions in mice. Brit. J. Pharmacol., 20, 389-398.

ITOKAWA Y. C., TANAKA C., KIMURA M., 1972. Effect of thiamin on serotonin levels in magnesium deficient animals. Metabolism, 21, 375-379. 
JASMIN G., 1961. Effect of Mg deficiency upon tissue histamine and inflammations in rats. Fed. Proc., 20, 257.

KRUSE H. D., ORENT E. R., McCOLLUM E. V., 1932. Studies on magnesium deficiency in animals. I. Symptomatology resulting from magnesium deprivation. J. biol. Chem., 96, 519-522.

MCCOLLUM E. V., ORENT E. R., 1931. Effects on the rat of deprivation of magnesium. J. Biol. Biochem., 30, $92: X X X$.

MEIER R. SCHULER W., DESAULLES P., 1950. Zur Frage des Mechanismus der Remmung des Bindegewebewachstums durch Cortisone. Experientia, 6, 469.

NIEMEGEERS C. J. E., VERBRUGGEN F. J., JANSSEN R. A. I., 1964. Effect of various drugs on carrageenin induced edema in the rat hind paw. J. Pharm. Pharmacol., 16, 817.

RAMSAY A. G., ELIOTT H. C., 1967. Effect of acetyisalicylic on ionic reabsorption in the renal tubule. Amer. J. Physiol., 213, 323-327.

RAYSSIGUIER Y., LARVOR P., AUGUSTI Y., DURLACH J., 1977. Serum proteins in magnesium-deficient rat. Ann. Biol. anim. Biophys., 17, 147-152.

RAYSSIGUIER Y., LARVOR P., BARLET J. P., 1973. Etude de l'influence d'un phosphonate de sodium sur le taux rénal de calcium chez le rat carencé en magnésium. $C$. R. Acad. Sci. Paris, Sér. D, 276, 2035-2038.

SILVESTRINI B., 1964. Methods for the study of anti-inflammatory drugs, 180. In GARATTINI S., DUKES M. N. E., Non steroidal anti-inflammatory drugs. Int. Symp. Congr. Ser., nº 82, Excerpta med. Amsterdam.

SPECTOR W. G., 1956. The mediation of altered capillary permeability in acute inflammation. J. Pothol. Bacteriol., 72, 367-380.

SPECTOR W. G., WILLOUGHBY D. A., 1959. Experimental suppression of the acute inflammatory changes of thermal injury. J. Pathol. Bacteriol., 78, 121-132.

WILHELMI G., 1965. Influence of non steroidal anti-inflammatory drugs on experimental serositis, 174-179. In GARATTINI S., DUKES M. N. E. Non steroidal anti-inflammatory drugs. Int. Symp., Congr. Ser., no 82, Excerpta med., Amsterdam.

WINTER C. A., RISLEY E. A., NUSS G. W., 1962. Carrageenin-induced edema in hind paw of the rat as an assay for anti-inflammatory drugs. Proc. Soc. exp. Biol. Med., 111, 544-547. 